\title{
Living on the edge: Does cut mean cure for pulmonary mucosa-associated lymphoid tissue?
}

\author{
Junaid Haroon, $\mathrm{MD},{ }^{\mathrm{a}}$ and Subroto Paul, $\mathrm{MD}, \mathrm{MPH}^{\mathrm{b}}$
}

\footnotetext{
From the ${ }^{\mathrm{a} D e p a r t m e n t ~ o f ~ S u r g e r y, ~ S a i n t ~ B a r n a b a s ~ M e d i c a l ~ C e n t e r ; ~ a n d ~}{ }^{\mathrm{b}}$ Department of Cardiothoracic Surgery, Saint Barnabas Medical Center, Newark Beth Israel Hospital, RWJBarnabas Health, Livingston, NJ. Disclosures: Authors have nothing to disclose with regard to commercial support.

Received for publication March 17, 2017; accepted for publication March 21, 2017; available ahead of print April $27,2017$.

Address for reprints: Subroto Paul, MD, MPH, Department of Cardiothoracic Surgery, RWJBarnabas Health, 94 Old Short Hills Rd, Suite 1172, Livingston, NJ 07039 (E-mail: Subroto.Paul@rwjbh.org).

J Thorac Cardiovasc Surg 2017;154:350-1

$0022-5223 / \$ 36.00$

Copyright (c) 2017 by The American Association for Thoracic Surgery

http://dx.doi.org/10.1016/j.jtcvs.2017.03.097
}

Pulmonary marginal zone B-cell lymphomas of mucosa-associated lymphoid tissue (MALT) are disorders comprising less than $1 \%$ of lung malignancies and non-Hodgkin lymphomas. Pulmonary MALT lymphoma is an indolent disease with the majority of patients presenting at an early stage. ${ }^{1}$ Symptoms are infrequent in these patients, with as many as one third having no respiratory symptoms. Classic B symptoms are even more infrequent. ${ }^{2}$ Thus, patients often are diagnosed on the basis of radiologic findings of single or multiple pulmonary nodules or consolidations. ${ }^{3}$ A definitive diagnosis requires histologic evaluation of tissue obtained via image-guided needle biopsy or minimally invasive surgical biopsy. Image-guided biopsies often are inadequate with a diagnostic specimen requiring a surgical biopsy. ${ }^{4}$ Current therapy options include surgical resection, chemotherapy, and targeted therapy such as rituximab. The results of surgical resection for early-stage pulmonary MALT (stage IE, IIE) are conflicting. There have been some studies supporting its use with improved outcomes and a prolonged disease-free survival, ${ }^{1,2,5}$ whereas other studies have suggested chemotherapy to be the preferred first-line therapy. ${ }^{6}$ The rarity of disease combined with the absence of symptoms makes it not only difficult to diagnose but also difficult to study and form consensus treatment guidelines. 5,7

In this issue of the Journal, Lee and colleagues ${ }^{8}$ review 51 patients with pulmonary MALT lymphoma to shed further light on this disorder. The authors find that given the indolent nature of the early-stage pulmonary MALT lymphomas, surgery alone may be the optimal therapy. The authors further suggest that sublobar resections that offer lung volume preservation and fewer complications may provide equivalent outcomes to lobectomy for peripheral lesions, although the limited sample size of the study makes it hard to make definitive conclusions. Because many patients are first diagnosed by surgical biopsy, the authors further argue disease. $^{8}$

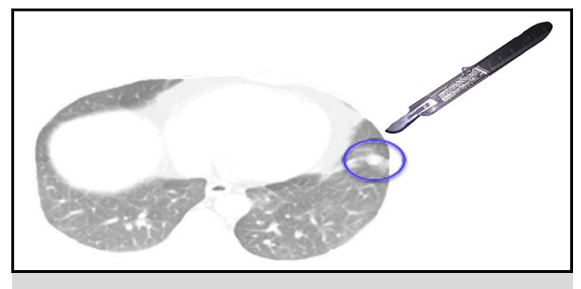

Surgical resection may be the best option for patients with early-stage pulmonary MALT.

Central Message

Pulmonary MALT is indolent in nature. Surgical resection is an appropriate diagnostic and therapeutic modality for patients with earlystage disease.

See Article page 342.

that resection can serve not only as a means of diagnosis but also as first-line therapy in those with early-stage

All studies focusing on rare disorders, including this study, ${ }^{8}$ are limited by small sample sizes. The small sample size combined with its retrospective design makes meaningful comparisons between different subgroups difficult to interpret. ${ }^{8}$ Randomized trials are the obvious gold standard but near impossible to complete with sufficient power for rare disorders. How then are we to obtain meaningful data to base treatment? To this end, rare diseases such as pulmonary MALT lymphomas will benefit from having shared international registries to allow pooling of data regarding the natural history of disease and the response to treatment to allow generation of treatment guidelines. Until then, the cut may be the cure for early-stage pulmonary MALT (Figure 1).

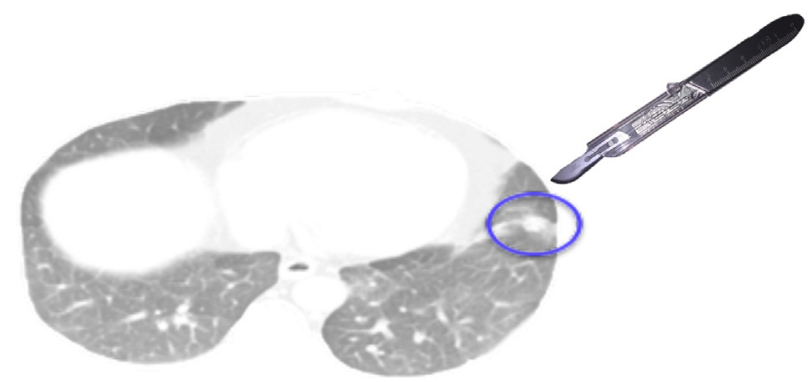

FIGURE 1. Surgical resection may be the best option for patients with early-stage pulmonary MALT. 


\section{References}

1. Sammassimo S, Pruneri G, Andreola G, Montoro J, Steffanoni S, Nowakowski GS, et al. A retrospective international study on primary extranodal marginal zone lymphoma of the lung (BALT lymphoma) on behalf of International Extranodal Lymphoma Study Group (IELSG). Hematol Oncol. 2016;34:177-83.

2. Stefanovic A, Fong T, Lossos IS. Pulmonary marginal zone lymphoma: a single centre experience and review of the SEER database. Leuk Lymphoma. 2008;49:1311-20.

3. Kurtin PJ, Myers JL, Adlakha H, Strickler JG, Lohse C, Pankratz VS, et al. Pathologic and clinical features of primary pulmonary extranodal marginal zone B-cell lymphoma of MALT type. Am J Surg Pathol. 2001;25:997-1008.

4. Ahmed S, Kussick SJ, Siddiqui AK, Bhuiya TA, Khan A, Sarewitz S, et al. Bronchial-associated lymphoid tissue lymphoma: a clinical study of a rare disease. Eur J Cancer. 2004;40:1320-6.
5. Ferraro P, Trastek VF, Adlakha H, Deschamps C, Allen MS, Pairolero PC Primary non-Hodgkin's lymphoma of the lung. Ann Thorac Surg. 2000;69: 993-7.

6. Zinzani PL, Pellegrini C, Gandolfi L, Casadei B, Derenzini E, Broccoli A, et al Extranodal marginal zone B-cell lymphoma of the lung: experience with fludarabine and mitoxantrone-containing regimens. Hematol Oncol. 2013;31: $183-8$.

7. Borie R, Wislez M, Antoine M, Copie-Bergman C, Thieblemont C, Cadranel J. Pulmonary mucosa-associated lymphoid tissue lymphoma revisited. Eur Respir J. 2016;48:1252.

8. Lee H, Yang B, Nam B, Jeong B-H, Shin S, Zo J Il, et al. Treatment outcomes in patients with extranodal marginal zone B-cell lymphoma of the lung. J Thorac Cardiovasc Surg. 2017;154:342-9. 